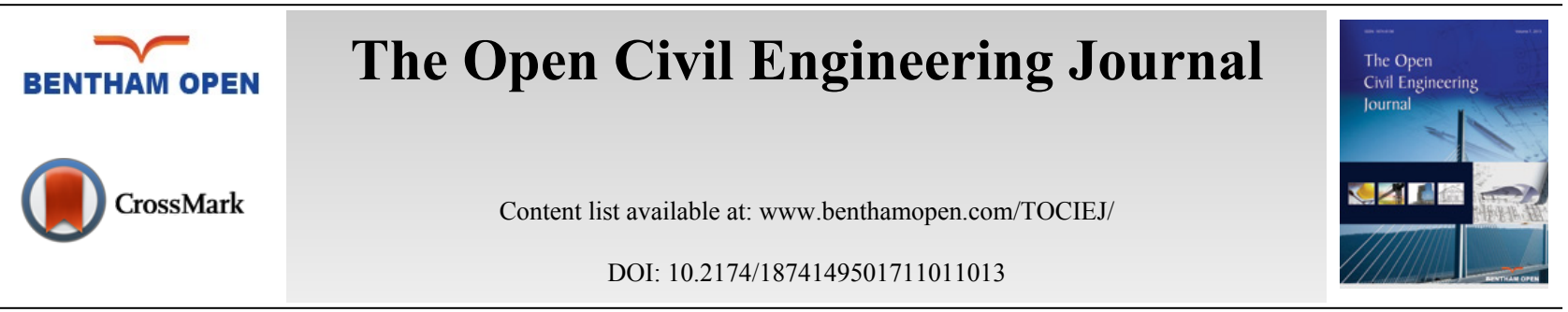

REVIEW ARTICLE

\title{
The State of Art on Super Structural Testing Machine in China
}

\author{
Yubin $\mathrm{Ma}^{1}$, Jinbao $\mathrm{Ji}^{1,2, *}$, Weiming Yan ${ }^{1,2}$ and Jing $\operatorname{Han}^{1}$ \\ ${ }^{\prime}$ Beijing Key Laboratory of Earthquake Engineering and Structural Retrofit, Beijing University of Technology, Beijing \\ 100124, China \\ ${ }^{2}$ Beijing Collaborative Innovation Center for Metropolitan Transportation, Beijing 100124, China
}

\begin{abstract}
As important test equipment to carry out full-scale structure testing and components failure mechanisms research, super structural testing machines have developed rapidly all over the world in recent years. The authors of this paper investigated, compared and analyzed the construction and the development trends of super structural testing machines in China. The test functions, the test space, the maximum tonnage and other technical indexes of super structural testing machines, which have been built in China, were described. The functions and the typical tests of a multi-functional structure test loading system $(40,000 \mathrm{kN})$ installed in the Beijing University of Technology were also discussed. The vibrations caused by the failure of brittle test pieces on this super structural testing machine were analyzed, and some suggestions to reduce the vibrations were given. It would be valuable for further development and the improvement of other super structural testing machines.
\end{abstract}

Keywords: Structural testing machine, Structure test, Brittleness specimen, Environment vibration, State of art, Tonnage.

\section{INTRODUCTION}

With the rapid growth of economy and continuous progress of industrial technology, civil structures are becoming larger and more complicated. Large-scale joint tests, large-scale structural tests and full-sized structural tests are essential for sophisticated structures. Therefore, an increasing number of super structural testing machines have been built around the world.

Super structural testing machines are essential test equipments to study the failure mechanisms of full-scale structures and components. Countries are scrambling to develop super structural testing machines with large tonnage (load $>10,000 \mathrm{kN})$ [1]. In this paper, the functions and the applications of some major super structural testing machines are summarized and analyzed. The performance and the typical tests of a multifunctional structure loading system $(40,000 \mathrm{kN})$ installed in the Beijing University of Technology are introduced in detail. Some problems related to the development of super structural testing machines are discussed.

\section{DEVELOPMENT OF SUPER STRUCTURAL TESTING MACHINE}

\subsection{Development of Super Structural Testing Machines in the World}

In the 1960s, the development of super structural testing machines began in Japan, which owns the largest number of testing machines in the world, involving universities, research institutes, steel enterprises, construction companies and shipbuilding factories [2 - 4]. Vertical testing machines and horizontal testing machines are two types of super structural testing machines. The vertical testing machine is mainly used for compression tests and is composed of a base, columns and beams. The loading cylinder is generally placed underground in order to lower the center of gravity and ensure stable loading. The upper beam and the lower beam are driven by a single or multiple cylinders to load specimens. Eccentric loads and vibration shock are mainly borne by the external frame. The horizontal testing machine

* Address correspondence to this author at the Beijing Key Laboratory of Earthquake Engineering and Structural Retrofit, Beijing University of Technology, Beijing, China; Tel: 0086-13161288669; E-mail: jinbao@bjut.edu.cn 
is mainly used for tensile tests, which do not need a huge base and large space. It is mainly composed of cylinders, columns, left beam and right beam. The two beams with trolley wheels can move freely on the rail, resulting in a long travel and a large load. The machine is suitable for test specimens that are long and heavy.

The loading capacity of super structural testing machines improved continuously with the strong support of government and other relevant agencies. During the early days, the loading capacity of vertical testing machines in Japan ranged from $10,000 \mathrm{kN}$ to $30,000 \mathrm{kN}$. The largest ones are Shimadzu structural compression testing machines $(30,000 \mathrm{kN})$ installed in Nihon University and Public Works Research Institute (PWRI). The capacity of horizontal testing machines increased from $10,000 \mathrm{kN}$ to $100,000 \mathrm{kN}$. The largest one is the Sumitomo Metal structural tensile testing machine $(100,000 \mathrm{kN})$, which is installed in Sumitomo Industrial Technology Research Center. It was also the largest horizontal structural tensile testing machine in the world. The major super testing machines in Japan are shown in Table 1.

Table 1. The development of super structural testing machines in Japan.

\begin{tabular}{|c|c|c|c|c|c|}
\hline No. & Type & Setting or Manufacturing Unit & Loading Capacity & Stroke & Cylinder \\
\hline 1 & \multirow{7}{*}{ Vertical } & Takenaka Corporation & $10,000 \mathrm{kN}$ & $1000 \mathrm{~mm}$ & 1 \\
\hline 2 & & Japan Building Research Institute & $10,000 \mathrm{kN}$ & $1000 \mathrm{~mm}$ & 1 \\
\hline 3 & & Kawasaki Steel Corporation & $10,000 \mathrm{kN}$ & $1000 \mathrm{~mm}$ & 1 \\
\hline 4 & & Faculty of Engineering, University of Tokyo & $20,000 \mathrm{kN}$ & $1000 \mathrm{~mm}$ & 1 \\
\hline 5 & & National Research Laboratory of Metrology & $20,000 \mathrm{kN}$ & - & 1 \\
\hline 6 & & College of Science and Technology, Nihon University & $30,000 \mathrm{kN}$ & $1000 \mathrm{~mm}$ & 5 \\
\hline 7 & & PWRI of Ministry of Construction & $30,000 \mathrm{kN}$ & $1200 \mathrm{~mm}$ & 5 \\
\hline 8 & \multirow{13}{*}{ Horizontal } & Shimadzu Corporation & $12,000 \mathrm{kN}$ & $1000 \mathrm{~mm}$ & 4 \\
\hline 9 & & Shimadzu Corporation & $17,000 \mathrm{kN}$ & $2000 \mathrm{~mm}$ & 4 \\
\hline 10 & & Osaka University & $20,000 \mathrm{kN}$ & $300 \mathrm{~mm}$ & 2 \\
\hline 11 & & Tokyo Test Machine Manufacturing & $24,000 \mathrm{kN}$ & - & 4 \\
\hline 12 & & Hitachi Research Institute & $28,000 \mathrm{kN}$ & $400 \mathrm{~mm}$ & 4 \\
\hline 13 & & MITI Ship Research Institute & $30,000 \mathrm{kN}$ & $200 \mathrm{~mm}$ & 1 \\
\hline 14 & & Nippon Steel Yawata & $30,000 \mathrm{kN}$ & $300 \mathrm{~mm}$ & 4 \\
\hline 15 & & Kobe Steel & $30,000 \mathrm{kN}$ & $500 \mathrm{~mm}$ & 4 \\
\hline 16 & & MITI Ship Research Institute & $40,000 \mathrm{kN}$ & $200 \mathrm{~mm}$ & - \\
\hline 17 & & Nippon Kokan (NKK) & $50,000 \mathrm{kN}$ & $300 \mathrm{~mm}$ & - \\
\hline 18 & & Nippon Steel & $80,000 \mathrm{kN}$ & $600 \mathrm{~mm}$ & 4 \\
\hline 19 & & Kawasaki Steel Corporation & $80,000 \mathrm{kN}$ & $700 \mathrm{~mm}$ & 4 \\
\hline 20 & & Sumitomo Industrial Technology Research Center & $100,000 \mathrm{kN}$ & $600 \mathrm{~mm}$ & 4 \\
\hline
\end{tabular}

In addition to the Japanese testing machines mentioned above, super structural testing machines of other countries are as follows. YAW7107 series electro-hydraulic servo pressure shear testing machines with the maximum loading capacity of $10,000 \mathrm{kN}$, which are developed by American Mechanical Testing and Simulation (MTS) Company. American MTS 311 series of large loading frame, the loading capacities of which are 10,000 kN, 15,000 kN, 20,000 $\mathrm{kN}$, and $30,000 \mathrm{kN}$. Furthermore, there are the $20,000 \mathrm{kN}$ compression testing machine of Federal Materials Testing Institute produced by Swiss Amsler Company [5], the 54,000 kN universal testing machine installed in the National Bureau of Standards and the 22,700 kN universal testing machine both produced by American Baldwin Company [6], the American MTS 10,000 kN electro-hydraulic servo pressure shear testing machine, the $100,000 \mathrm{kN}$ tensile testing machine of West German Schenck Company, the 20,000 kN testing machine installed in the Berlin Material Inspection Bureau [7], and the $100,000 \mathrm{kN}$ hydraulic servo tensile testing machine installed in the National Materials Laboratory of University of Stuttgart.

\subsection{The Development of Super Structural Testing Machines in China}

China Changchun testing machine factory successfully produced the first 5,000 $\mathrm{kN}$ pressure testing machine [8] in 1959. In 1975, it produced a $6,000 \mathrm{kN}$ universal structural testing machine. Although the loading capacity of this machine is smaller compared to the $10,000 \mathrm{kN}$ testing machine, it is far more difficult to design and manufacture. It laid the foundation for the development and the production of super testing machines in China. In 1982, YES-1000 compression testing machine with a maximum loading capacity of $1000 \mathrm{kN}$ was developed. The machine was composed of four vertical columns, two horizontal beams and a single cylinder; the distance between upper beam and 
lower beam is $1,200 \mathrm{~mm}$. Strictly speaking, this is the first super structural testing machine in China. Soon afterwards, factories and research institutes produced a series of high level testing machines. They initially applied electronic technology to control, measure and record then imported electro-hydraulic servo control system, and finally applied computer technology successfully.

At present, different types of large-tonnage test loading equipment are being developed and manufactured by Tianshui Hongshan testing machine factory, who can represent super testing machine manufacturers in China. Though the loading capacity of the machines increased gradually, the test function was still simple. For example, the $15,000 \mathrm{kN}$ electro-hydraulic servo horizontal tensile testing machine is mainly used for tensile strength tests of long specimens, general metal or non-metallic materials. The $20,000 \mathrm{kN}$ electro-hydraulic servo compression testing machine is mainly used for compression, flexural and shear tests of metals and compression and flexural performance tests of non-metallic materials [9]. The 30,000 kN electro-hydraulic servo multifunctional pressure shear testing machine is mainly used for mechanical property tests and comprehensive tests of large structures [10].

The first high-strength, wide-plate tensile testing machine in China is $20 \mathrm{~m}$ in length, $5 \mathrm{~m}$ in width and $4.5 \mathrm{~m}$ in height and has a maximum tensile capacity of 50, $000 \mathrm{kN}$ [11]. In 2006, the 52,000 kN electric-hydraulic servo bridge bearing testing machine, developed by Italian Alga Company for Zhuzhou Times New Material Technology Co., Ltd., was used for the static and dynamic performance tests of bridge bearing. It was the largest tonnage of domestic bridge bearing testing machine [12]. Beijing Fuli Tongda Science and Technology (FTS) Co., Ltd. also developed a multifunctional structural testing machine $(40,000 \mathrm{kN})$ that can achieve various functions of vertical compression tests, vertical tension and compression tests and bidirectional pressure shear tests.

Besides, some other factories or research institutes also have the ability to develop testing machines, such as Changchun Testing Machine Research Institute, Jinan Testing Machine Group, Shenzhen SANS Group, Tianshui Hongshan Testing Machine Co., Ltd. and Shanghai Hualong Test Instruments Corporation [13]. With the urgent need of large-scale structure testing in the research of civil engineering, many universities and research institutes' laboratories in China are also equipped with super structural testing equipment, as shown in Table 2.

Table 2. The development of super structural testing machines in China.

\begin{tabular}{|c|c|c|c|c|}
\hline No. & Setting or Manufacturing Unit & Equipment Name & Load Capacity & Space \\
\hline 1 & Dalian University of Technology & Electro-hydraulic servo compression testing machine & $10,000 \mathrm{kN}$ & - \\
\hline 2 & $\begin{array}{l}\text { Huazhong University of Science and } \\
\text { Technology }\end{array}$ & Electro-hydraulic servo loading system & $20,000 \mathrm{kN}$ & - \\
\hline 3 & Tongji University & Large multifunctional structural experiment system & $10,000 \mathrm{kN}$ & $4 \mathrm{~m} \times 2 \mathrm{~m} \times 5 \mathrm{~m}$ \\
\hline 4 & Tongji University & General purpose loading system(GPLS) & $30,000 \mathrm{kN}$ & Up to $6.1 \mathrm{~m}$ \\
\hline 5 & Tsinghua University & Spatial multifunctional structure loading device & $20,000 \mathrm{kN}$ & $6 \mathrm{~m} \times 6 \mathrm{~m} \times 8 \mathrm{~m}$ \\
\hline 6 & The Hong Kong Polytechnic University & Large multifunctional structural testing system & $10,000 \mathrm{kN}$ & - \\
\hline 7 & Beijing University of Technology & Multifunctional structure loading system & $40,000 \mathrm{kN}$ & $6 \mathrm{~m} \times 4 \mathrm{~m} \times 8 \mathrm{~m}$ \\
\hline 8 & $\begin{array}{c}\text { Taiwan National Earthquake Engineering } \\
\text { Research Center }\end{array}$ & Multi-axial testing system(MATS) & $60,000 \mathrm{kN}$ & Up to $5 \mathrm{~m}$ \\
\hline 9 & Tianshui Hongshan testing machine Co., Ltd. & $\begin{array}{l}\text { Large multifunctional electro-hydraulic servo pressure shear } \\
\text { testing machine }\end{array}$ & $30,000 \mathrm{kN}$ & Up to $0.3 \mathrm{~m}$ \\
\hline 10 & Nanjing University of Technology & Pressure shear testing machine & $10,000 \mathrm{kN}$ & - \\
\hline 11 & Shanghai Institute of Technology & $\begin{array}{l}\text { Large electro-hydraulic servo multifunctional structure } \\
\text { testing system }\end{array}$ & $10,000 \mathrm{kN}$ & - \\
\hline 12 & Nantong University & Large multifunctional structure testing system & $10,000 \mathrm{kN}$ & - \\
\hline 13 & Beijing Fluid Control System Corp. & $\begin{array}{l}\text { Rubber bearing pressure shear electro-hydraulic servo } \\
\text { testing system }\end{array}$ & $20,000 \mathrm{kN}$ & - \\
\hline 14 & Shanghai Jiao tong University & Large structure testing system & $10,000 \mathrm{kN}$ & - \\
\hline 15 & Tianshui Hongshan testing machine Co., Ltd. & High strength wide plate tensile testing machine & $50,000 \mathrm{kN}$ & $\begin{array}{c}5 \mathrm{~m} \times 2.2 \mathrm{~m} \times 0.12 \\
\mathrm{~m}\end{array}$ \\
\hline 16 & $\begin{array}{c}\text { Zhuzhou Times New Material Technology } \\
\text { Co., Ltd }\end{array}$ & Electro-hydraulic servo bridge bearing testing machine & $52,000 \mathrm{kN}$ & $2 \mathrm{~m} \times 2 \mathrm{~m} \times 1.15 \mathrm{~m}$ \\
\hline 17 & Southwest Jiaotong University & Multifunctional bridge rubber bearing testing machine & $120,000 \mathrm{kN}$ & - \\
\hline 18 & Jilin University & $\begin{array}{l}\text { Super large dynamic and static multifunctional testing } \\
\text { machine }\end{array}$ & $120,000 \mathrm{kN}$ & $4 \mathrm{~m} \times 2 \mathrm{~m} \times 10 \mathrm{~m}$ \\
\hline 19 & China state construction technical center & The facility of advanced structural testing(FAST) & $108,000 \mathrm{kN}$ & Up to $10 \mathrm{~m}$ \\
\hline
\end{tabular}


Tongji University has built a large multifunctional structural experiment system $(10,000 \mathrm{kN})$ with an investment of 6 million yuan RMB by the funding of Shanghai's leading academic discipline project and the Ministry of Education "211 Project", as shown in Fig. (1) [14]. The main body of the machine is a double-door type frame structure with the beam that can move up and down along the columns. The servo control system has six channels, enabling simultaneous $10,000 \mathrm{kN}$ compression and 3,000 $\mathrm{kN}$ stretching, 3,000 $\mathrm{kN}$ upper lateral push and 1,500 $\mathrm{kN}$ lower lateral pull with original follow-up servo control mode. The testing machine has a test space of $4 \mathrm{~m} \times 2 \mathrm{~m} \times 5 \mathrm{~m}$ (length $\times$ width $\times$ height) that enables the stress state of large structural component under complex loads to be simulated.

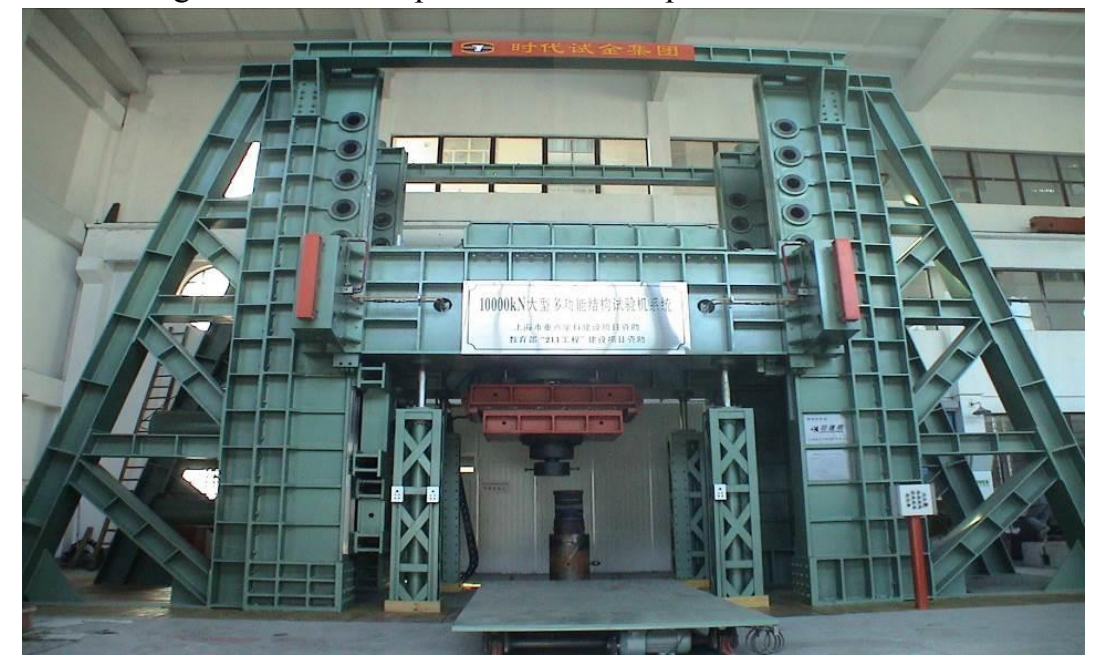

Fig. (1). Large multifunctional structural experiment system.

The large structural multifunctional spatial load device, developed by Tsinghua University and Beijing Fluid Control System Corporation, is composed of a three-dimensional frame and a steel-concrete composite bottom beam foundation below the ground. It is a self-balancing system that can carry out three-dimensional loading [15], as shown in Fig. (2). The device can be used for electric hydraulic servo coordination loading of structure or component in any position by adopting an innovative hydraulic step lifting mechanism. The maximum spatial dimension of the structure is $6 \mathrm{~m} \times 6 \mathrm{~m} \times 8 \mathrm{~m}$ (length $\times$ width $\times$ height). The maximum vertical load is $20,000 \mathrm{kN}$, and the maximum horizontal load is $3,000 \mathrm{kN}$.

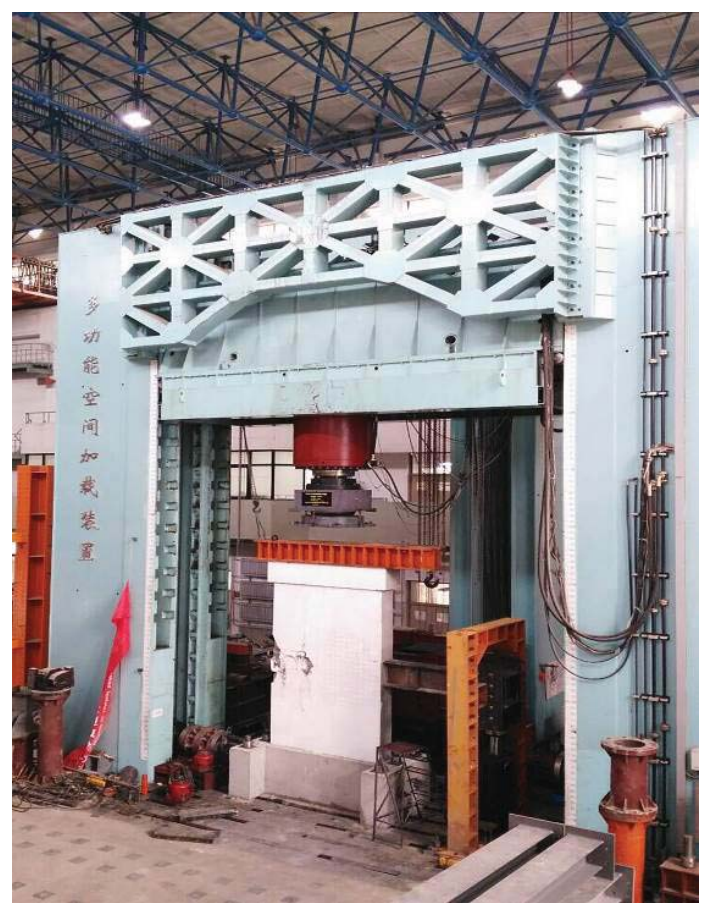

Fig. (2). Large structural multifunctional spatial load device. 
The large multifunctional structural testing system of The Hong Kong Polytechnic University, manufactured by Hangzhou POPWIL Electromechanical Control Engineering Co., Ltd., is mainly used for the mechanical performance tests of beams, columns, joints, walls and framed structures, as shown in Fig. (3). The body of the machine is a doubledoor type frame structure, and the test space can be adjusted by the movement of the beam along the columns. The maximum vertical load is $10,000 \mathrm{kN}$ and the maximum horizontal load is $1,500 \mathrm{kN}$.

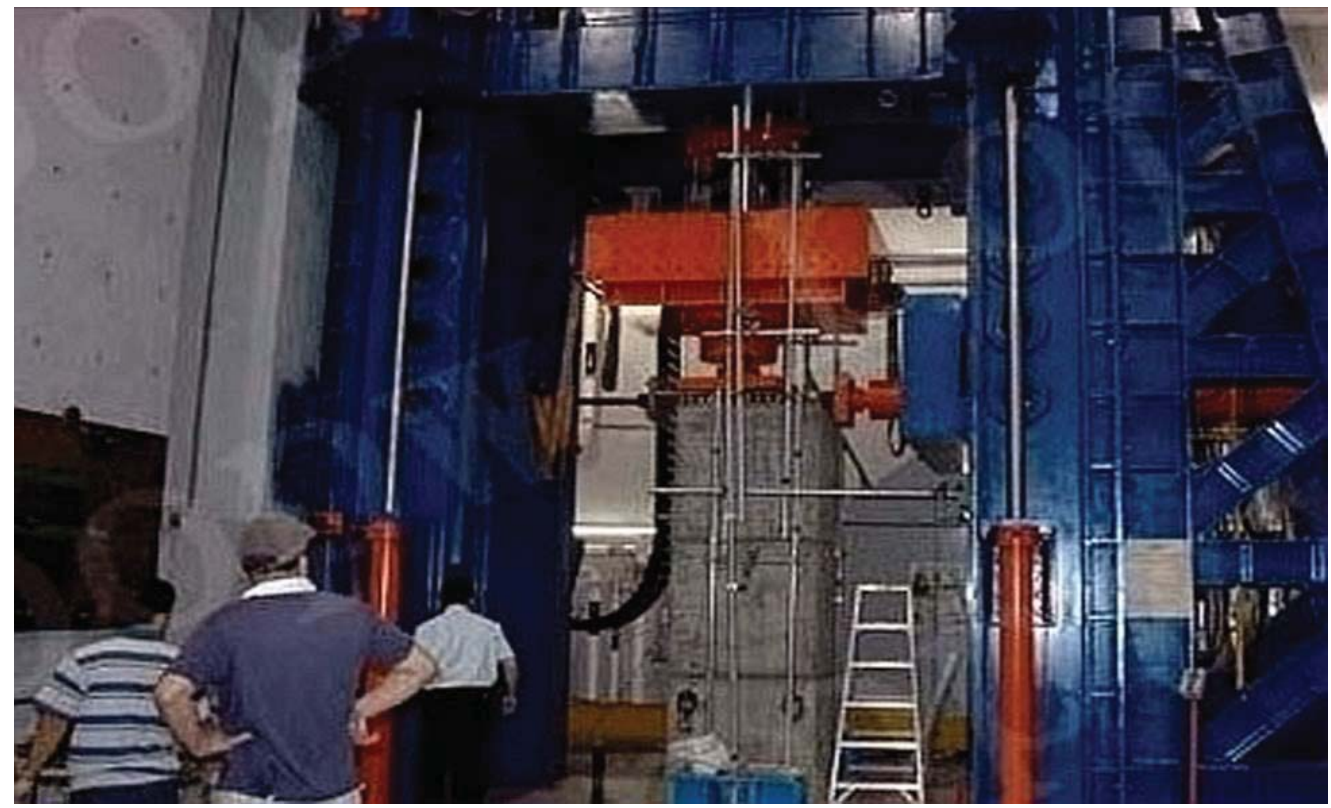

Fig. (3). Large multifunctional structural testing system.

The new multi-axial testing system (MATS) installed in Taiwan National Earthquake Engineering Research Center adopts the design of prestressed concrete and is a six degree of freedom testing system. The main frame is made up of two A-shaped prestressed reinforced concrete members and reinforced concrete foundation, as shown in Fig. (4). It can accommodate specimens with a maximum height of $5 \mathrm{~m}$. The maximum vertical load capacity is $60,000 \mathrm{kN}$, the maximum horizontal tensile capacity is $7,000 \mathrm{kN}$ approximately and the maximum horizontal displacement is $1.2 \mathrm{~m}$. The multi-axial testing system can carry out the tests of vibration isolation bearing, column, velocity-type damper, diagonal brace member, beam-column joint and shear wall.

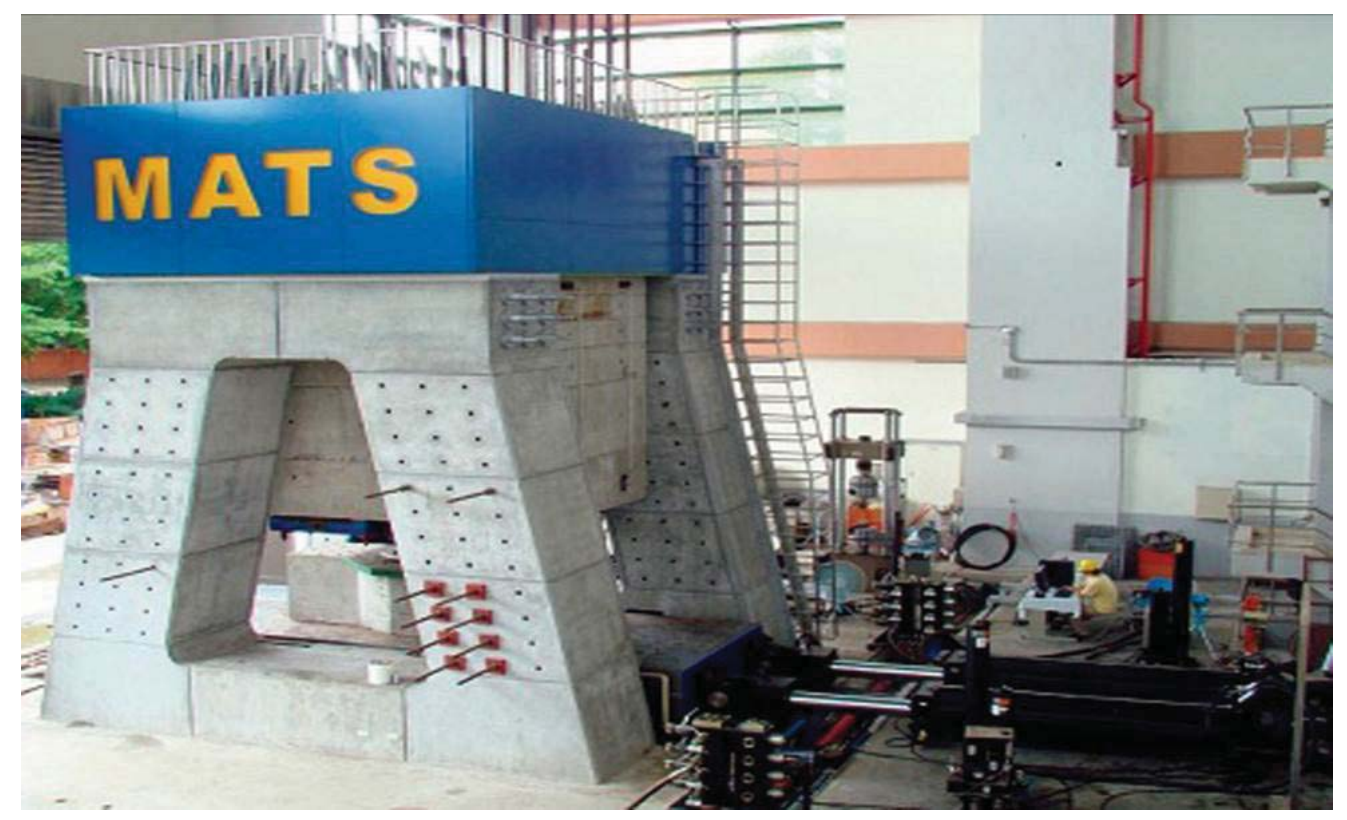

Fig. (4). Multi-axial testing system (MATS). 


\subsection{The Development Trends of Super Structural Testing Machines}

In recent years, super structural testing machines have largely developed in China. It has increasingly become one of the most essential test equipments of research institutes. With the progress of industrial technology, scientific research has higher requirement for super structural testing machines both in terms of the quantity and the function. Super vertical testing machines have been developed from a simple compression testing machine to an intelligent electrohydraulic servo control multifunctional universal testing machine, which can carry on compression, bending, tension and low cycle fatigue tests. The development of super structural testing machines has the following trends:

1. High load capacity, large test space. As the size of structures or component models gradually becomes larger, test equipment with larger test space and higher tonnage loading capacity is needed.

2. Intellectualization and automation of control system. The rapid development of micro electronic technology provides for the automation and intelligence of super structural testing machine to realize the intelligent adjustment of control system and the automatic processing of test data.

3. Multifunction and high performance. In order to meet the different requirements of test, the function of testing machines need to expand, the multichannel coordinated loading mode and the simulate conditions of actual multi degrees of freedom need to develop.

4. High precision, high stability. Apply advanced control algorithm to improve the test precision accurately according to the given conditions of the test, and reduce the vibration of machine equipment caused by the fracture of specimen.

5. Electro mechanical hydraulic integration. The advanced mechanical and electronic technologies should be fully utilized to promote perfection and high integration of the whole hydraulic system.

\section{MULTIFUNCTIONAL STRUCTURE LOADING SYSTEM (40,000 KN)}

\subsection{Introduction of the System}

Multifunctional structure loading system $(40,000 \mathrm{kN})$ in the structure experimental center of Beijing University of Technology has a single 40,000 $\mathrm{kN}$ vertical main actuator, one set of 4,000 $\mathrm{kN}$ horizontal actuator and two sets of 2,000 $\mathrm{kN}$ vertical actuators [16]. The main frame is composed of four counterforce frames, a top frame, two beams (upper and lower), key teeth, loading cylinders and a foundation, as shown in Fig. (5).

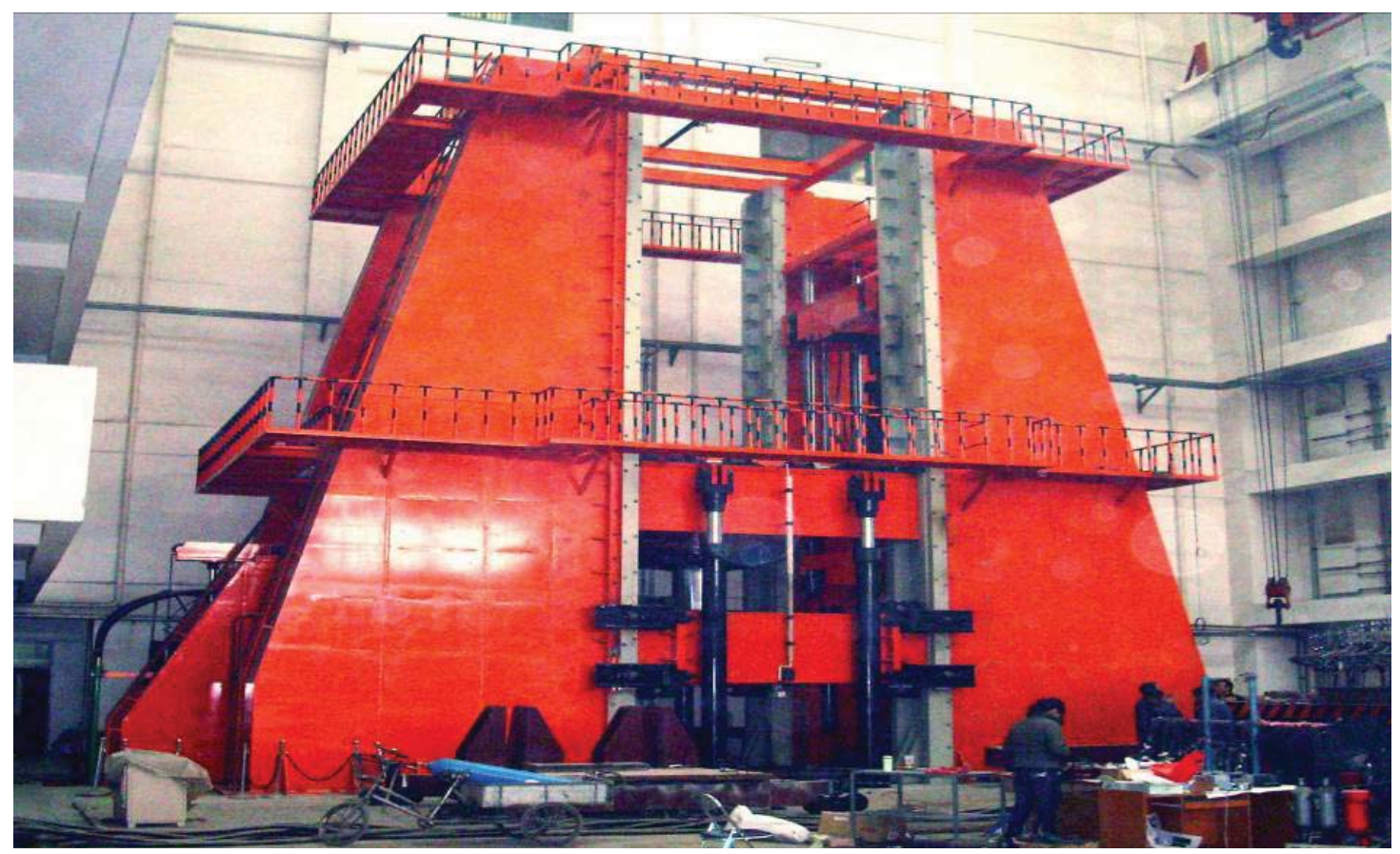

Fig. (5). Multifunctional structure loading system $(40000 \mathrm{kN})$. 
The specific test functions of the system are as follows:

1. Pseudo-static tests of prototype beam-column joints can be carried out by the combination of a $40,000 \mathrm{kN}$ compression test machine and two sets of $2,000 \mathrm{kN}$ dynamic loading system. Three-dimensional pseudo-static tests of beam-column spatial joints can also be carried out with an additional $500 \mathrm{kN}$ dynamic loading system.

2. One-way or two-way compression shear tests of rubber bearings with a diameter of $1.8 \mathrm{~m}$ can be carried out by the combination of a $40,000 \mathrm{kN}$ compression test machine and a 4,000 kN dynamic loading system.

3. Pseudo-dynamic tests of prototype beam-column joints with simulating seismic input at the bottom can be carried out by the combination of a $40,000 \mathrm{kN}$ compression test machine and a 4,000 $\mathrm{kN}$ dynamic loading system.

4. Performance tests of dampers can be carried out by the combination of a $4,000 \mathrm{kN}$ dynamic loading system and a test frame.

5. Fatigue tests of components can be carried out by a $2,000 \mathrm{kN}$ dynamic loading system independently.

6. Pseudo-dynamic tests of model structures can be carried out by the combination of two sets of $2,000 \mathrm{kN}$ dynamic loading system and other dynamic load actuators.

7. The $40,000 \mathrm{kN}$ compression testing machine can be used independently as a general large tonnage material testing machine.

\subsection{Problems Encountered in Typical Tests}

At present, the system has completed more than 500 pieces of rubber cushion, prototype beam-column joints, eccentric columns and other tests.

However, the vibration caused by the sudden fracture of test specimen in the later stage of loading process has caused adverse effects when using the $40,000 \mathrm{kN}$ main actuator for brittle specimen compression tests, as shown in Fig. (6). The vibration of the offices surrounding the laboratory is felt strongly. The acceleration of vertical vibration has been measured up to $3 \mathrm{~g}$, as shown in Fig. (7), which has seriously affected the work of teachers and students around the laboratory. The cracking and deformation of filler walls around the experimental center brings potential safety hazards. The upper beam, the lower beams, the key teeth and other parts of the testing machine are prone to fatigue damage under the strong vibration. The control system of the testing machine is easily damaged under repeated impact. A large number of full-scale masonry structures and plain concrete tests are unable to be completed due to the excessive vibration of the testing machine. Therefore, it is urgent to solve the vibration problem of the $40,000 \mathrm{kN}$ testing machine.

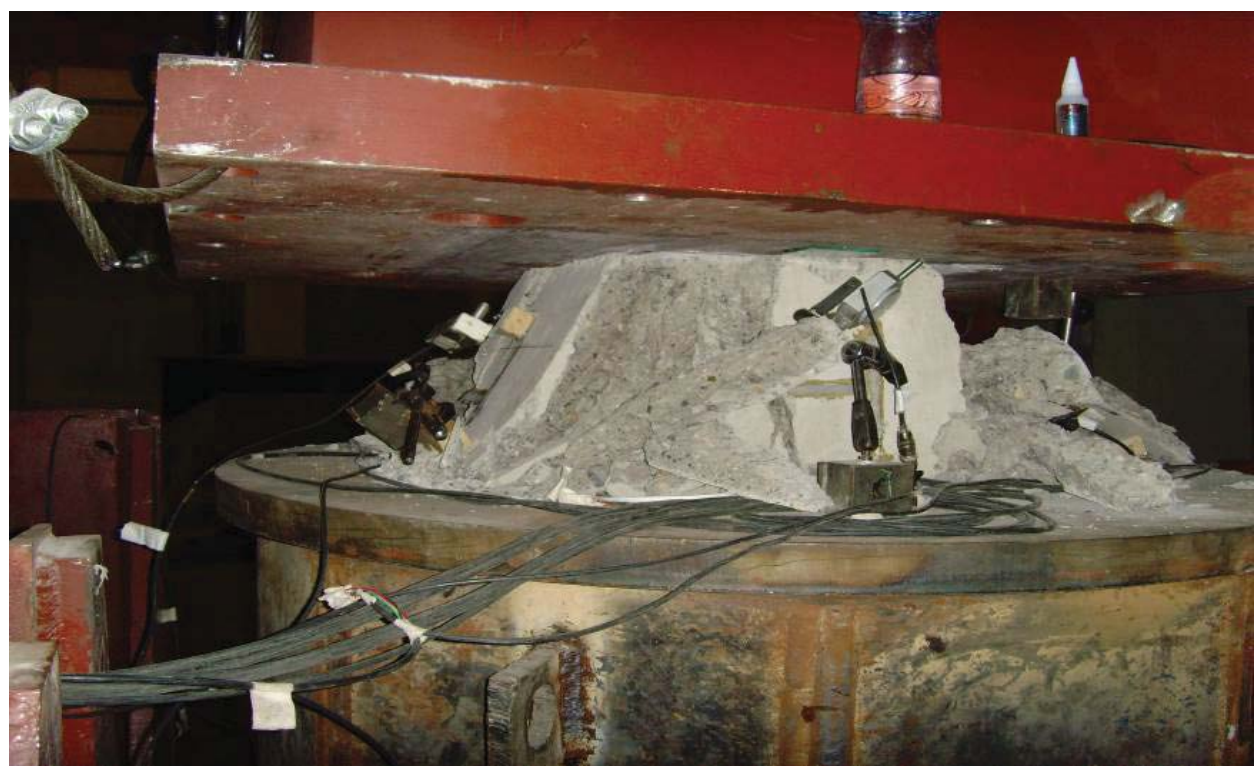

Fig. (6). The axial compression performance test of brittleness specimen. 


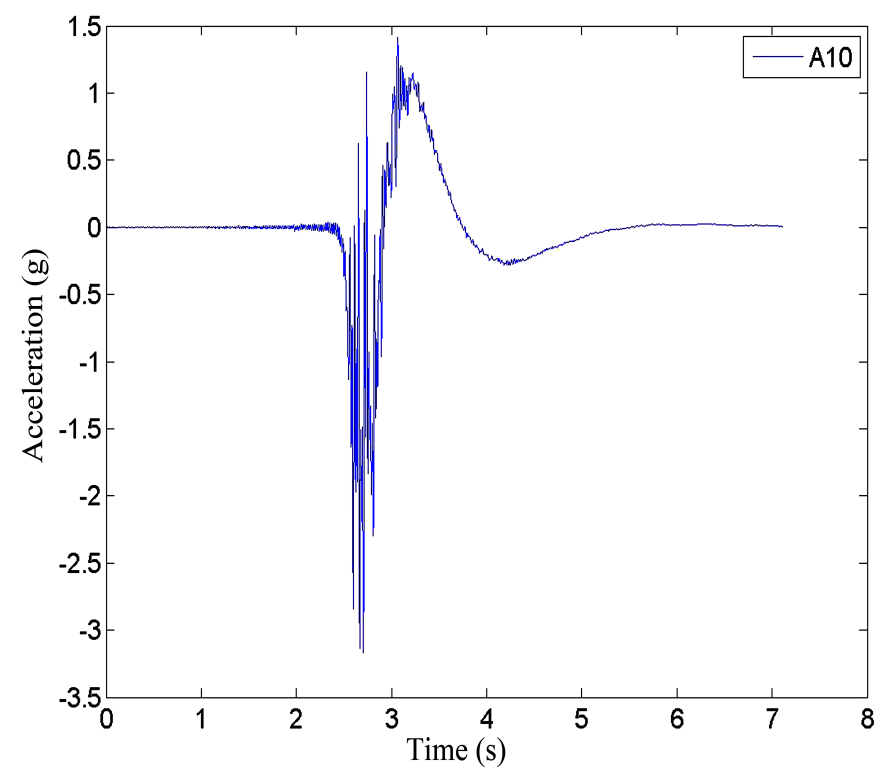

Fig. (7). The acceleration curve of the frame in the brittle failure process.

\section{VIBRATION REDUCTION METHODS OF SUPER STRUCTURAL TESTING MACHINE}

In recent years, much attention has been devoted to the problem of vibration caused by the fracture of specimen in super structural testing machines. However, there are limited studies on the vibration reduction of super structural testing machine. Two sets of buffer cylinders are set on the fixed beam of the $20,000 \mathrm{kN}$ structural testing machine of Japan Tokyo Koki Co., Ltd. to buffer the impact of the sudden fracture of test specimen, as shown in Fig. (8). Similarly, four sets of hydraulic buffers for tensile load are set in the Sumitomo 100,000 kN structural tensile testing machine. Each set has maximum absorption capacity of $500 \mathrm{kN}$, and the integrated buffer capacity is $2,000 \mathrm{kN}$.

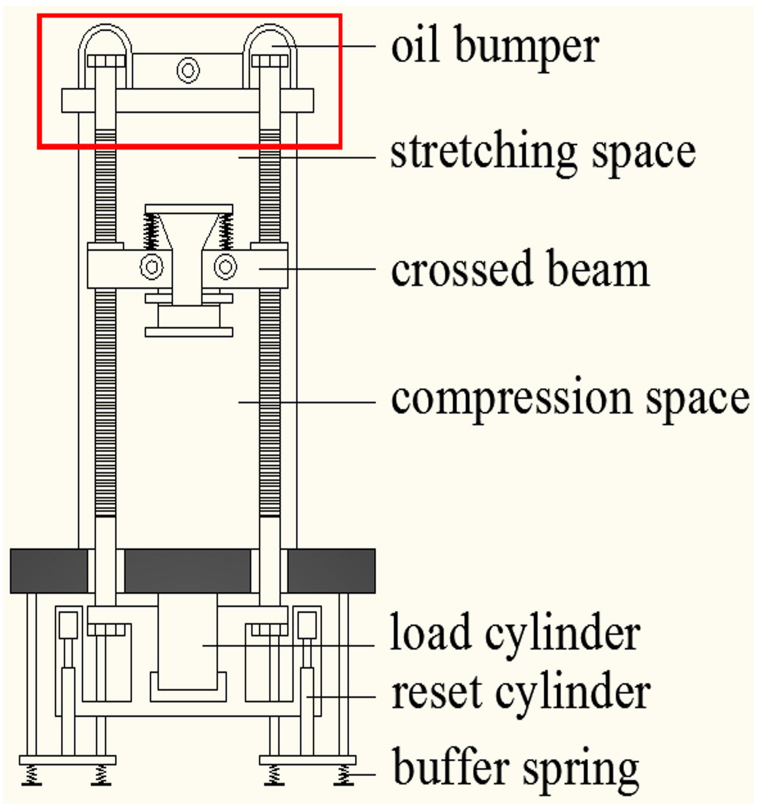

Fig. (8). Diagram of oil bumper.

One of the major problems of super structural testing machines is that the fracture of specimen will generate an impact load, which has the acceleration of $100 \mathrm{~g}$ or greater. Zhu Qilin [5] mentioned this problem in the introduction of the Swiss 20,000 kN compression testing machine. The structure of the machine is a suspension system with four braces that is set in an elastic buffer block to buffer $90 \%$ of the energy, as shown in Fig. (9). In addition, there are six hydraulic dampers in each loading cylinder to further reduce the impact load. 


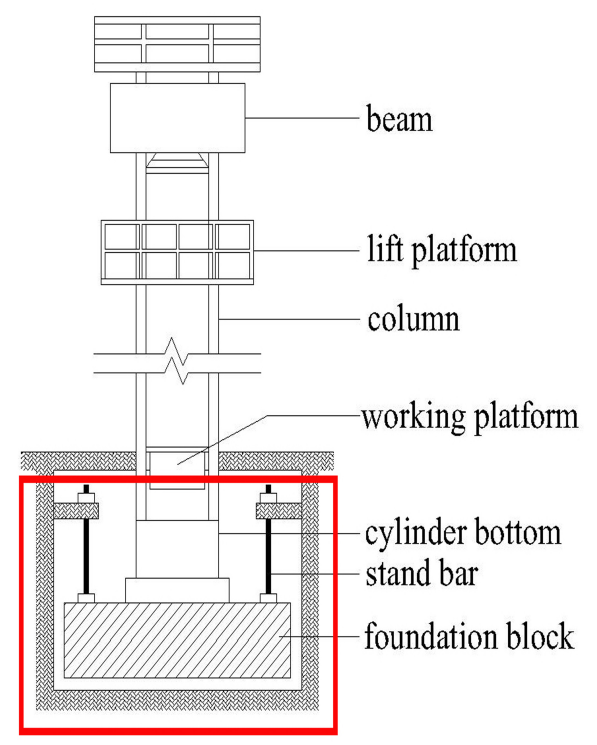

Fig. (9). Diagram of the elastic buffer block.

The fast-releasing energy could eject partial or full specimens from the testing machine, which can cause serious damages. In order to absorb the elastic energy that is released when the specimen is damaged, the elastic foundation, the spring damper and the hydraulic shock absorber are generally adopted, as shown in Fig. (10). The reduction of the vibration produced by the fracture of specimen cannot be ignored in the design of super structural testing machines.

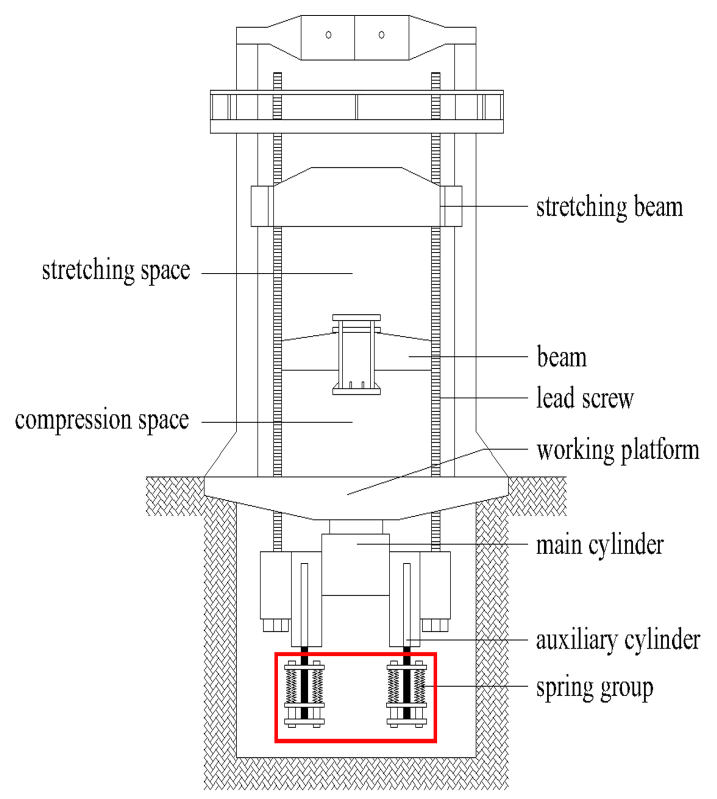

Fig. (10). Diagram of spring damper.

Xue Guangxin of Jilin University [17] carried out the dynamic analysis on vertical vibration of workbench due to the fracture of specimen of 100MN multifunctional test system. He proposed that dampers could be set up to reduce the vibration of the workbench. In the analysis for effects of specimen fracture on facility of advanced structural testing, Li Guoqiang [18] mentioned the use of a vibration isolation layer below the base of equipment to reduce the influence of the test system on the surrounding office area, as shown in Fig. (11). The number of vibration isolators has a significant effect on the vibration isolation effect. Too many isolators result in waste because each one cannot have a full play to the function. To the contrary, when the quantity is too small, damages can easily happen because the stress of the specimen is too large to exceed the technical requirement of the vibration isolator. 


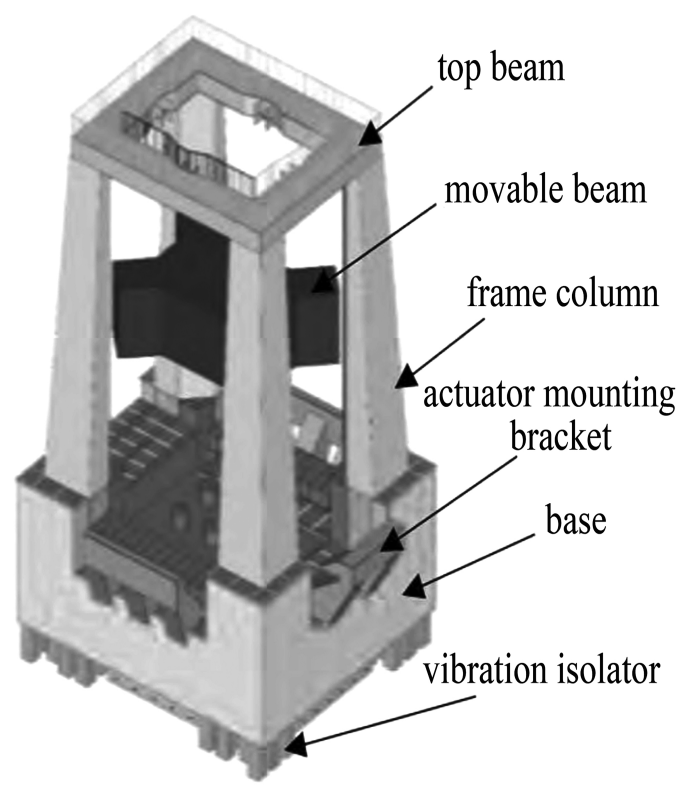

Fig. (11). Diagram of vibration isolation layer.

\section{CONCLUSION}

In this paper, the development of super structural testing machines all over the world is summarized. The test function, the test space, the largest tonnage and other technical indexes of super structural testing machines in China are presented, and the development trends of super structural testing machines are examined. The brittleness test of a multifunctional structural loading system $(40,000 \mathrm{kN})$ in the Beijing University of Technology is discussed. The magnitude of vibrations caused by the failure of specimens in the super structural testing machine is analyzed, and some vibration reduction methods are suggested. Adapting such methods would be valuable for further development and improvement of other super structural testing machines.

\section{CONSENT FOR PUBLICATION}

Not applicable.

\section{CONFLICT OF INTEREST}

The authors declare no conflict of interest, financial or otherwise.

\section{ACKNOWLEDGEMENTS}

This work is sponsored by the Opening Foundation of Beijing Key Lab of Earthquake Engineering and Structural Retrofit.

\section{REFERENCES}

[1] Q.L. Zhu, "Foreign super structural machine", Engineering \& Test, vol. 06, pp. 43-53, 1981.

[2] T.R. Wang, "The status of super structural testing machine in Japan (1)", Engineering \& Test, vol. 3, pp. 46-52, 1985.

[3] T.R. Wang, "Super structural testing machine in Japan (2)", Engineering \& Test, vol. 04, pp. 39-50, 1985.

[4] T.R. Wang, "Super structural testing machine in Japan (3)", Engineering \& Test, vol. 05, pp. 47-53, 1985.

[5] Q.L. Zhu, "2,000 ton compression testing machine", Engineering \& Test, vol. 04, pp. 53-58, 1984.

[6] Q.L. Zhu, "12 million pounds universal testing machine installed in the national bureau of USA standards", Structural \& Environmental Engineering, vol. 02, pp. 1-9, 1977.

[7] Q.L. Zhu, "Application of three stage servo valve in testing machine", Engineering \& Test, vol. 3, pp. 58-65, 1984.

[8] W.G. Pan, "Discussion on several problems in the development of super testing machine in China", China Instrumentation, vol. 2, pp. 22-23+17, 1983.

[9] E. Zhang, Structural design and analysis of the oversize multifunctional structure test loading system., Beijing University of Technology: 
Beijing, China, 2005.

[10] J.W. Zhang, J. Hong, D.C. Wang, and L.L. Zhang, "Development of large-scale multifunction load-shear test machine with electro-hydraulic servo control", Chinese Hydraulics \& Pneumatics, vol. 06, pp. 64-67, 2010.

[11] D. Yang, "Hongshan company developed the first domestic high strength tensile testing machine", Tianshui Daily. 2013-04-18(001).

[12] M. Yan, L.F. Liu, and J.P. Cao, "52MN bridge rubber bearing test machine and its application", Mechanical Engineer, vol. 08, pp. 12-14, 2010

[13] X.L. Li, Research on Measurement and Control System of 120MN Bridge Rubber Bearing Multi-function Test Machine, Southwest Jiaotong University: Chengdu, China, 2012.

[14] Z.Y. Shen, X.N. Guo, and Y.Q. Li, "Validation and analysis of loading performance of the 10000kN-large multifunctional structural experiment system", In: Structural Engineers, vol. 04. 2006, pp. 54-59+76.

[15] Structural engineering institute of Tsinghua University, "Development of large structural multifunctional spatial load device", In: Proceedings of the Symposium on Structural Testing and Testing Technology and Structural Testing in Civil Engineering, CCES, Beijing, China, 2006.

[16] L.M. Chen, Zh.B. Li, H.Y. Zhou, W.M. Yan, H.Q. Li, H.H. Huang, and J. Liu, "40,000kN multifunctional electro-hydraulic servo load system", Structural Engineers, vol. 27, pp. 27-30, 2011.

[17] G.X. Xue, Study on Mechanical Capability of 100MN Multifunctional Test System, Jilin University: Changchun, China, 2015.

[18] G.Q. Li, P. Wang, and J.Y. Sun, "Numerical analysis for effects of specimen fracture on facility of advanced structural testing (FAST)", Journal of Vibration and Shock, vol. 35, pp. 216-221, 2016.

(C) 2017 Ma et al.

This is an open access article distributed under the terms of the Creative Commons Attribution 4.0 International Public License (CC-BY 4.0), a copy of which is available at: https://creativecommons.org/licenses/by/4.0/legalcode. This license permits unrestricted use, distribution, and reproduction in any medium, provided the original author and source are credited. 